\title{
Aetiology of community acquired pneumonia in Valencia, Spain: a multicentre prospective study
}

\author{
J Blanquer, R Blanquer, R Borrás, D Nauffal, P Morales, R Menéndez, I Subias, \\ L Herrero, J Redón, J Pascual
}

\begin{abstract}
A year long multicentre prospective study was carried out in the Valencia region of Spain, to determine the cause of community acquired pneumonia. The study was based on 510 of 833 patients with pneumonia. Of these, 462 were admitted to hospital, where 31 patients died. A cause was established in only 281 cases-208 of bacterial, 60 of viral, and 13 of mixed infection. The most common microorganisms were Streptococcus pneumoniae (14.5\%), Legionella sp (14\%), Influenza virus (8\%), and Mycoplasma pneumoniae (4\%). There was a higher incidence of Legionella sp than in other studies.
\end{abstract}

The cause of community acquired pneumonia is often difficult to establish. The most effective methods are often invasive and cannot always be justified, whereas a serological diagnosis is too late to be of therapeutic use. These circumstances and the changing causative organisms of pneumonia ${ }^{1}$ require a detailed knowledge of the microorganisms responsible in a particular environment. Many studies have shown that the microbiological cause of pneumonia is related to geographical location, though the influence of the identification methods used is also important. ${ }^{2-9}$

We determined the aetiology of pneumonia acquired in Valencia by studying emergency admissions to four hospitals.

Hospital Clínico
Universitario,

Facultad Medicina,

Universidad de

Valencia, Valencia

$\mathrm{J}$ Blanquer

$\mathrm{R}$ Blanquer

R Borrás

Hospital La Fe,

Valencia

D Nauffal

P Morales

R Menéndez

Hospital La

Magdalena, Castellón

I Subias

L Herrero

Hospital de Sagunto, Sagunto, Valencia,

Spain

J Redón

J Pascual

Reprint requests to:

Dr J Blanquer, Servicio de

Medicina Intensiva, Hospita

Clínico Universitario, Avda

Blasco Ibáñez 17, 46010-

Valencia, Spain

Accepted 17 April 1991 risk factors ${ }^{10}$ and were applied by physicians in each participating centre.

After history taking, physical examination, and chest radiology, blood and where possible lower respiratory tract secretions were obtained. Blood was collected for biochemical, haematological, and microbiological analysis (blood culture, detection of capsular antigens, and the first sample for detection of antibodies). Arterial blood gas tensions were determined when appropriate. Thoracocentesis, transtracheal aspiration, percutaneous aspiration biopsy of the lung, or necropsy was performed to obtain samples in some cases.

All patients underwent clinical, radiological, and serological follow up after 21 and 42 days. All cases were followed to resolution or death.

\section{MICROBIOLOGICAL METHODS}

Three blood cultures were performed before treatment. Tracheobronchial secretions were cultured after washing. Smears were stained by Gram's method and bacterial morphology was determined. ${ }^{11}{ }^{12}$ Semiquantitative counting was carried out on positive cultures. ${ }^{13}$ Where legionellosis was suspected direct immunofluorescence tests for Legionella pneumophila serogroups $1-6$ and $L$ micdade $i$ were performed, and culture attempted in BCYE-alpha medium. ${ }^{14} 15$

Capsular antigens of Streptococcus pneumoniae and Haemophilus influenzae serotype b were sought in the first blood samples and respiratory secretions, after treatment of the sample with $0 \cdot 1 \mathrm{M}$ EDTA and heat, ${ }^{16}$ by agglutination of latex particles sensitised with anti- $H$ influenzae serotype $\mathrm{b}$ (Wellcome) ${ }^{17}$ and polyvalent anti-S pneumoniae serum (Omniserum Serum Institum), which had been previously adsorbed with other common streptococci of the oropharyngeal microflora. ${ }^{18}$

The serum samples obtained on days 1,21 , and 42 were assayed for antibody to influenza viruses $A$ and $B$; parainfluenza viruses 1,2 , and 3; adenovirus; respiratory syncytial virus; cytomegalovirus; herpes simplex viruses 1 and 2; Mycoplasma pneumoniae; Chlamydia psittaci; and Coxiella burnetti by complement fixation. Antibodies to Legionella sp were determined by indirect immunofluorescence. ${ }^{19}$

\section{CRITERIA FOR AETIOLOGICAL DIAGNOSIS}

Bacterial pneumonia was established by the detection of bacteria or their antigens in blood or respiratory samples. Pneumonia due to Legionella, $C$ burnetti, $C$ psittaci, $M$ pneumon$i a e$, and viruses was diagnosed by a fourfold rise in titre in paired samples.

$S$ pneumoniae was accepted as the cause if it was cultured in blood or pleural fluid, if 
Table 1 Aetiology of pneumonia in relation to hospital admission and death

\begin{tabular}{|c|c|c|c|c|}
\hline & \multicolumn{4}{|c|}{ No $(\%)$ of patients } \\
\hline & Inpatients & Outpatients & Total & No of deaths \\
\hline $\begin{array}{l}\text { Number } \\
\text { (Mean age (y) }\end{array}$ & $\begin{array}{c}462(90 \cdot 6) \\
59 \cdot 9_{+}^{+}\end{array}$ & $\begin{array}{l}48(9 \cdot 4) \\
40 \cdot 8\end{array}$ & $\begin{array}{l}510 \\
57 \cdot 9\end{array}$ & $\begin{array}{l}31 \\
68 \cdot 7)\end{array}$ \\
\hline Cause not established & $209(45 \cdot 2)$ & $20(41 \cdot 6)$ & $229(44 \cdot 9)$ & 10 \\
\hline $\begin{array}{l}\text { Bacterial } \\
\text { Streptococcus pneumoniae } \\
\text { Legionella sp } \\
\text { Mycoplasma pneumoniae } \\
\text { Enterobacteriaceae } \\
\text { Haemophilus influenzae } \\
\text { Staphylococcus aureus } \\
\text { Pseudomonas aeruginosa } \\
\text { Coxiella burnetti } \\
\text { Other } \dagger\end{array}$ & $\begin{array}{r}190(41 \cdot 1) \\
68(14 \cdot 7) \\
64(13 \cdot 8) \\
16(3 \cdot 5)_{+}^{+} \\
11 \\
9 \\
8 \\
4 \\
3 \\
7\end{array}$ & $\begin{array}{l}18(37 \cdot 5) \\
6(12 \cdot 5) \\
6(12 \cdot 5) \\
6(12 \cdot 5) \\
- \\
- \\
- \\
-\end{array}$ & $\begin{array}{c}208(40 \cdot 8) \\
74(14 \cdot 5) \\
70(13 \cdot 7) \\
22(4 \cdot 3) \\
11(2 \cdot 1) \\
9(1 \cdot 8) \\
8(1 \cdot 5) \\
4(0 \cdot 8) \\
3(0 \cdot 6) \\
7(1 \cdot 4)\end{array}$ & $\begin{array}{r}18 \\
7 \\
7 \\
3 \S \\
1\end{array}$ \\
\hline $\begin{array}{l}\text { Viral } \\
\text { Influenza A } \\
\text { Influenza B } \\
\text { Parainfluenza } 3 \\
\text { Respiratory syncytial virus } \\
\text { Adenovirus }\end{array}$ & $\begin{array}{l}50(10 \cdot 8) \\
26(5 \cdot 6) \\
10(2 \cdot 2) \\
8(1 \cdot 7) \\
5(1 \cdot 1) \\
1(0 \cdot 2)\end{array}$ & $\begin{array}{l}10(20 \cdot 8) \\
4(8 \cdot 3) \\
3(6 \cdot 2) \\
1(2 \cdot 1) \\
1(2 \cdot 1) \\
1(2 \cdot 1)\end{array}$ & $\begin{array}{l}60(11 \cdot 8) \\
30(5 \cdot 9) \\
13(2 \cdot 5) \\
9(1 \cdot 8) \\
6(1 \cdot 2) \\
2(0 \cdot 4)\end{array}$ & \\
\hline Mixed infection & $13(2 \cdot 8)$ & - & $13(2 \cdot 5)$ & 3 \\
\hline
\end{tabular}

^Klebsiella pneumoniae (7) and Escherichia coli (4).

$\dagger S$ viridans (2), Haemophilus parainfluenzae (2), Actinomyces naeslundii (1). Chlamydia psittaci (1), non-fermenting Gram negative bacillus (1).

${ }_{ \pm} \mathrm{p}<0.001$.

$\S K$ pneumoniae (2), E coli (1).

pneumococcal antigens were detected, or, in the absence of these, the presence of Gram positive encapsulated diplococci on the Gram stain and culture of $S$ pneumoniae or detection of capsular antigens in respiratory tract secretions (except in patients with chronic airways obstruction). ${ }^{40}$ The diagnosis of pneumonia caused by Gram negative bacteria was based on established criteria. ${ }^{21}$ The diagnosis of pneumonia caused by $H$ influenzae was based on the criteria used for pneumococcal pneumonia.

\section{STATISTICAL ANALYSIS}

Analysis was by $\chi^{2}$ test and Fisher's exact test for qualitative variables. Student's $t$ test was used for quantitative variables. Values of $p$ below 0.05 were considered significant.

\section{Results}

Of the 833 patients with community acquired pneumonia diagnosed during the study, 323 $(39 \%)$ were excluded for the following reasons: obstructive pneumonitis, tuberculosis, prior

Table 2 Predisposing factors

\begin{tabular}{lrr}
\hline & No & $\%$ \\
\hline Smokers & 236 & $46 \cdot 3$ \\
Chronic airways obstruction & 169 & $33 \cdot 1$ \\
Diabetes mellitus & 75 & $14 \cdot 7$ \\
Cardiovascular disease & 70 & $13 \cdot 7$ \\
Previous pneumonia & 66 & $12 \cdot 9$ \\
Alcohol & 57 & $11 \cdot 2$ \\
Bronchiectasis & 29 & $5 \cdot 7$ \\
Cerebrovascular accident & 22 & $4 \cdot 3$ \\
Neoplasia & 14 & $2 \cdot 8$ \\
Asthma & 11 & $2 \cdot 2$ \\
Drug abuse & 7 & $1 \cdot 4$ \\
Immunosuppression & 5 & $1 \cdot 0$ \\
\hline
\end{tabular}

${ }^{\star}$ Consumption $>100 \mathrm{~g} /$ day . treatment with antibiotics, and incomplete study data. The remaining 510 patients comprised $355(70 \%)$ males and $155(30 \%)$ females and were aged 15-92 (mean 58) years. Hospital admission was necessary for 462 patients $(91 \%)$, the remaining 48 being treated as outpatients. There were differences in mean age and the incidence of pneumonia caused by $M$ pneumoniae $(\mathrm{p}<0.001)$ between these groups (table 1).

Predisposing disease (table 2) was present in 393 patients $(77 \%)$, chronic airways obstruction being the most frequent (169 cases). Smoking was reported by $236(46 \%)$ of the patients.

There was no significant seasonal pattern, though the incidence was greater during winter and spring than in summer and autumn (288v 222 cases).

A causal agent was determined in 281 cases (55\%): $208(41 \%)$ were due to a bacterial infection, $60(12 \%)$ to a virus, and the remaining 13 cases $(2 \cdot 5 \%)$ to other microorganisms (table 1). Sputum or tracheobronchial secretions were obtained in 346 patients $(67 \cdot 5 \%)$. Of these specimens, $171(49 \%)$ were adequate for microbiological study and $87(51 \%)$ were diagnostic. Blood culture was diagnostic in 28 patients $(5 \cdot 5 \%)$ (table 3$)$.

\section{BACTERIAL PNEUMONIA}

$S$ pneumoniae was responsible for 74 cases of bacterial pneumonia (14.5\%), Legionella sp for 70 (14\%), M pneumoniae for $22(4 \%)$, and $H$ influenzae for nine (2\%) (tables 1 and 3).

Pneumococcal pneumonia was diagnosed by culture in 36 cases $(7 \%)$, by capsular antigen detection in $27(5 \%)$, and by culture with antigen detection in 11 cases $(2 \%)$. Pneumonia caused by Legionella sp was diagnosed by indirect immunofluorescence in 67 of 70 cases. 
Table 3 Diagnostic methods in bacterial pneumonia

\begin{tabular}{|c|c|c|c|c|c|c|c|c|}
\hline \multirow[b]{2}{*}{ Microorganisms } & \multirow[b]{2}{*}{$n$} & \multicolumn{3}{|l|}{ Culture } & \multicolumn{2}{|c|}{ Capsular antigen } & \multirow[b]{2}{*}{$D F A$} & \multirow[b]{2}{*}{$S C$} \\
\hline & & $\begin{array}{l}\text { Respiratory } \\
\text { specimen }\end{array}$ & Blood & Other & $\begin{array}{l}\text { Respiratory } \\
\text { specimen }\end{array}$ & Blood & & \\
\hline Streptococcus pneumoniae & 74 & 31 & 20 & 3 & 31 & 10 & & \\
\hline Legionella sp & 70 & & & & & & 3 & 68 \\
\hline Mycoplasma pneumoniae & 22 & & & & & & & 22 \\
\hline Enterobacteriaceae & 11 & 6 & 4 & 1 & & & & \\
\hline Haemophilus influenzae & 9 & 7 & & & 2 & 2 & & \\
\hline Staphylococcus aureus & 8 & 2 & 4 & 3 & & & & \\
\hline Pseudomonas aeruginosa & 4 & 3 & & 2 & & & & \\
\hline Chlamydia burnetti & 3 & & & & & & & 3 \\
\hline Others & 7 & 2 & & 4 & & & & 1 \\
\hline Total & 208 & 51 & 28 & 13 & 33 & 12 & 3 & 94 \\
\hline
\end{tabular}

DFA-direct immunofluorescence; SC - seroconversion.

Two patients were diagnosed by direct immunofluorescence and one by both direct and indirect immunofluorescence (tables 3 and 4).

VIRAL PNEUMONIA

The 60 cases of viral pneumonia were all diagnosed by seroconversion, influenza virus $A$ being the main organism identified (table 1 ).

\section{OTHER CAUSES}

Thirteen $(2.5 \%)$ cases of mixed cause pneumonia occurred, of which eight were infections with two or more bacteria and three were mixed bacterial and viral pneumonia. $S$ pneumoniae was the cause of seven cases of mixed pneumonia and Legionella $\mathrm{sp}$ of three (table 5).

\section{DEATHS DUE TO PNEUMONIA}

Thirty one patients $(6 \%)$, with a mean age of $68 \cdot 7$ years, died, all having been admitted to hospital. Seventeen deaths were a direct result of pneumonia, and 14 were due to coincidental factors. Ten deaths occurred with pneumonia of unknown cause, seven with Legionella sp, and seven with $S$ pneumoniae (table 1 ).

\section{Discussion}

The cause of pneumonia was established in half the cases studied. Most cases were caused by bacteria; only $12 \%$ were caused by viruses and $2.5 \%$ by a mixed infection. We have used the term bacterial pneumonia to include bacterial and atypical pneumonia, as have others. ${ }^{22}$ In the present study, as in previous studies, 2452223 typical bacterial pneumonias predominated, most cases being caused by $S$ pneumoniae.

In our study $S$ pneumoniae and Legionella sp were responsible for over half of all the cases of

Table 4 Diagnostic methods in pneumococcal pneumonia

\begin{tabular}{lcccc}
\hline & Culture & Antigen & Both & Total \\
\hline Respiratory specimens & 14 & 18 & 10 & 42 \\
Blood & 12 & 6 & 1 & 19 \\
Respiratory specimens and blood & 7 & 3 & & 10 \\
Other & 3 & & 11 & 74 \\
$\quad$ Total & 36 & 27 & & \\
\hline
\end{tabular}

*With appreciable Gram staining of the respiratory secretions. bacterial pneumonia, followed by $M$ pneumoniae, several species of Gram negative bacteria, and Staphylococcus aureus. A smaller proportion of cases of pneumonia was due to $S$ pneumoniae and a higher proportion to Legionella sp than in other studies. The frequency of $S$ pneumoniae in community acquired pneumonia has varied from $14 \%$ to $36 \%,{ }^{3682223}$ with occasional lower proportions. ${ }^{724}$ Our diagnosis of pneumococcal pneumonia was based on isolation from blood and respiratory tract secretions and the detection of capsular antigens, whereas others have used detection of specific antibodies. ${ }^{62}$ Blood culture was diagnostic in a quarter of cases of typical bacterial pneumonia, including those due to pneumococcus, which is a lower yield than in early studies and higher than in recent studies. ${ }^{2-5}$

The high percentage of Legionella sp infections we observed is similar to the proportions reported previously. ${ }^{4225}$ This organism probably replaces the $M$ pneumoniae infections seen in other series. Many cases of pneumonia of unknown cause are considered to be bacterial and probably pneumococcal in origin, especially when such patients have been treated with antibiotics; the possible saprophytic behaviour of $S$ pneumoniae means that its aetiological role can be accepted only when there are adequate guarantees, whereas Legionella $\mathrm{sp}$ is always considered to be a pathogen. Although the incidence of Legionella sp varies within a geographical area, ${ }^{48}$ its importance as a cause of pneumonia in our study is clear. ${ }^{26-29}$ Another probable reason for the high incidence of Legionella $\mathrm{sp}$ in our study is the methods of identification we used. Blood was collected at the start of the study and after 21 and 42 days for indirect immunofluorescence testing; this

Table 5 Aetiology of mixed pneumonia

\begin{tabular}{lc}
\hline Aetiological agents & $\begin{array}{l}\text { No of } \\
\text { cases }\end{array}$ \\
\hline Streptococcus pneumoniae + other bacteria & 4 \\
S pneumoniae + virus & 2 \\
Legionella sp + other bacteria & 2 \\
Sneumoniae + Legionella sp & 1 \\
Mixed (other bacteria) & 1 \\
Mixed (other bacteria + virus) & 1 \\
Mixed (viruses) & 2 \\
Total & 13 \\
\hline
\end{tabular}


yields more positive results as the interval between samples is increased. ${ }^{29} \mathrm{~A}$ high prevalence of antibodies to $L$ pneumophila 1 occurs in the healthy population in the Valencian community ${ }^{30}$ and $L$ pneumophila has been isolated in the water distribution system of this community. ${ }^{31} 32$

The incidence of $M$ pneumoniae was similar to that found in some previous studies ${ }^{27}$ and less than in others. ${ }^{356}$ All of our patients acquired pneumonia in the community and most were aged under $50 . .^{357}$ The incidence of pneumonia caused by other Gram negative bacteria, excluding Legionella sp, was similar to that observed in other studies. ${ }^{34}$

About $20 \%$ of cases of pneumonia with an identified cause were due to a virus. As in other studies, ${ }^{238}$ half of all cases of viral pneumonia were caused by influenza virus $A$, the rest being due mainly to influenza virus $\mathbf{B}$ and parainfluenza virus 3 .

In practice, the cause of community acquired pneumonia should be established. In many cases sputum culture and blood culture are sufficient. ${ }^{23}$ More invasive techniques should be reserved for special cases, such as necrotising pneumonitis, nosocomial pneumonia, and pneumonia associated with immunosuppression. For identification of $S$ pneumoniae sputum culture has been rated fairly low. ${ }^{33}$ Minimising oropharyngeal contamination ${ }^{34}$ and careful culture of sputum samples offers an $80 \%$ sensitivity and $72 \%$ specificity. ${ }^{35}$ The detection of capsular antigens in respiratory secretions is faster than culture and avoids the problem of oropharyngeal contamination. ${ }^{36}$ It is diagnostic if positivity coincides with the microorganism isolated in blood, sputum, or other body fluids. ${ }^{36}{ }^{37}$ The limitation of relying on antigen detection alone is that antigens may be detected in the respiratory secretions of patients with chronic bronchitis. ${ }^{20}$ Mortality was similar to that reported previously ${ }^{3}$ in that death was limited to patients admitted to hospital. Pneumonia of unknown aetiology or caused by Legionella sp and $S$ pneumoniae with bacteraemia was associated with a risk of death.

1 Fick RB, Reynolds HY. Changing spectrum of pneumonia. News media creation or clinical reality? $A m J$ Med 1983;74:1-8.

2 Dorff GJ, Rytel MW, Farmer SG, Scalon G. Etiologies and characteristic features of pneumonias in a municipal hospital. Am J Med Sci 1976;266:349-58.

3 White RJ, Blainey AD, Harrison KJ, Clarke SKR. Causes of pneumonia presenting to a district general hospital. Thorax 1981;36:566-70.

4 MacFarlane JT, Finch RG, Ward MJ, Macrae AD. Hospital study of adult community-acquired pneumonia. Lancet 1982;ii:255-8.

5 Berntsson E, Blomberg J, Lagergard T, Trollfors B. Etiology of community-acquired pneumonia in patients requiring hospitalisation. Eur J Clin Microbiol 1985;4:268-72.

6 Berntsson E, Lagergard T, Strannegard O, Trollfors B. Etiology of community-acquired pneumonia in outpatients. Eur J Clin Microbiol 1986;5:446-7.

7 Capell S, Javaloyas M, Sanchez C, et al. Etiologia de la neumonia extrahospitalaria en un medio urbano. Med Clin (Barcelona) 1985;84:4-7.

8 Woodhead MA, MacFarlane JT, McCracken JS, Rose DH, Finch RG. Prospective study of the etiology and outcome of pneumonia in the community. Lancet $1987 ; \mathrm{i}: 671-4$.

9 Ausina V, Coll C, Sambeat M, et al. Prospective study on the etiology of community-acquired pneumonia in children and adults in Spain. Eur $J$ Clin Microbiol Infect Dis 1988;7:342-7.

10 Lerner AM, Jankauskas K. The classic bacterial pneumonias. Diseases a Month 1975; Feb:1-46.

11 Murray PR, Washington JA. II. Microscopic and bacteriologic analysis of expectorated sputum. Mayo Clin Proc 1975;50:339-44.

12 Rein MF, Gwaltney JH, O'Brien WM, Jennings RH, Mandell GL. Accuracy of Gram's stain in identifying pneumococci in sputum. JAMA 1978;239:2671-3.

13 Bartlett JG, Brewer NS, Ryan KJ. Laboratory diagnosis of lower respiratory tract infections In: Washington JA, ed. Cumitech 7 , Cumulative Techniques and Procedures in Clinical Microbiology). Washington DC: American Clinical Microbiology/. Washington
Society for Microbiology, 1987:1-15.

14 Cherry WB, McKinney N. Detection in clinical specimens by direct immunofluorescence. In: Jones GL, Hebert GA eds. Legionnaires: the disease, the bacterium and methodology. Atlanta: US Department of Health, Education, and Welfare, 1979:92-103.

15 Edelstein PH. Improved semiselective medium for isolation of Legionella pneumophila from contaminated clinical and environmental specimens. J Clin Microbiol 1981;14 298-303.

16 Smith LP, Hunter KW, Hemming VG, Fischer GW. Improved detection of bacterial antigens by latex agglutination after rapid extraction from body fluids. $J$ Clin Microbiol 1984;20:981-4.

17 Severin WPJ. Latex agglutination in the diagnosis of meningococcal meningitis. J Clin Pathol 1972;25:1079-82.

18 Holmberg H, Danielsson D, Hardie J, Krook A, Whiley R. Cross-reaction between alpha-streptococci and ommiserum, a polyvalent pneumococcal serum, demonstrated by direct immunofluorescence, immunoelectroosmophoresis, and latex agglutination. J Clin Microbiol phoresis, and

19 Wilkinson HW, Filkes BJ, Cruce DD. Indirect immunofluorescence test for diagnosis of legionnaires' disease evidence for serogroup diversity of legionnaires' disease bacterial antigen and for multiple specificity of human antibodies. J Clin Microbiol 1979;9:379-83.

20 Edwards EA, Coonrod JA. Coagglutination and counterimmunoelectrophoresis for detection of pneumococcal antigens in the sputum of pneumonia patients. $J$ Clin Microbiol 1980;11:488-91.

21 Tillotson JR, Lerner AM. Pneumonias caused by Gram negative bacilli. Medicine Baltimore 1986;45:65-76.

22 Kerttula Y, Leinonen M, Koskela M, Makela PH. The aetiology of pneumonia. Application of bacterial serology and basic laboratory methods. J Infect 1987;14:21-30.

23 Levy M, Dromer F, Brion N, Leturdu F, Carbon C. Community-acquired pneumonia. Importance of initial noninvasive bacteriologic and radiographic investigations. Chest 1988;92:43-8.

24 Kennedy DH, Borland W. How common legionnaires' disease. Lancet 1983;i:360-5.

25 Muder R, Yu VL, Fang GD. Community-acquired Legionnaires' disease. Semin Respir Infect 1989;4:32-9.

26 Reid D, Grist NR, Najera R. Illness associated with "package tours": a combined Spanish-Scottish study. Bull WHO 1978;56:117-22.

27 Juan G, Navarro R, Lloret J. Legionnaires' disease in Luxent. Spain [abstract]. Am Rev Respir Dis 1985; 131:A230.

28 Redon J, Borras R, Vila B, et al. Neumonia nosocomial por Legionella pneumophila: estudio prospectivo. Med Clin (Barcelona) 1986;87:363-7.

29 Monforte R, Estruch R, Vidal J, Cervera R, UrbanoMarquez A. Delayed seroconversion in legionnaire's disease. Lancet 1988;ii:513.

30 Borras R, Blanquer J, Millan E, Prat J, Sanfeliu P, Garcia de Lomas J. Prevalencia de anticuerpos anti-Legionella pneumophila serogrupo 1 en la región valenciana. Enf Infec Microb Clin 1987;5:462-4.

31 Redon J. Legionella pneumophila en Sagunto: estudio clinicoepidemiologico. University of Valencia, doctoral thesis, 1986.

32 Muñoz C. Marcadores epidemilógicos moleculares de Legionella pneumophila en la comunidad Valenciana. University of Valencia, doctoral thesis, 1989.

33 Barrett-Connors $E$. The nonvalue of sputum culture in the diagnosis of pneumococcal pneumonia. Am Rev Respir Dis 1971;103:845-8.

34 Washington II, JA. Noninvasive diagnostic techniques for lower respiratory infections. In: Pennington JE, ed. Respiratory infections: diagnosis and management. New York: Raven Press, 1983:41-54.

35 Perlino CA. Laboratory diagnosis of pneumonia due to Streptococcus pneumoniae. J Infect Dis 1984;150:139-44.

36 McIntyre M. Detection of capsulated Haemophilus influenzae in chest infection by counter-current immunoelectrophoresis. J Clin Pathol 1978;31:31-4.

37 Austrian R. Pneumococcal pneumonia. Diagnostic, epidemiologic, therapeutic and prophylactic considerations. Chest 1988;90:738-43. 